\title{
A Systematic Overview of Issues for Developing EFL Learners' Oral English Communication Skills
}

\author{
Prodhan Mahbub Ibna Seraj, Hadina Habil \\ Universiti Teknologi Malaysia \\ Correspondence concerning this article should be addressed to Prodhan Mahbub Ibna Seraj, TESL, School \\ of Education, Universiti Teknologi Malaysia, 81310, Johor Bahru, Malaysia. \\ E-mail:mahbub@graduate.utm.my
}

\begin{abstract}
The objective of this systematic review is to present a critical overview of current studies to explore issues such as the factors causing EFL learners' poor oral performance and the teaching and assessment methods of oral English communication skills (OECSs) for developing tertiary level learners' OECSs in EFL contexts. For this purpose, 51 empirical studies of the 2907 retrieved from SpringerLink, SCOPUS, Web of Science, and the Google Scholar database that were published between 2010 and 2019 in different EFL contexts were analyzed. This study followed the Preferred Reporting Items for Systematic Review and Meta-analyses (PRISMA) guidelines and was analyzed thematically using NVIVO 12, followed by the Mendeley reference management software. Studies that were conducted in native English contexts and nonempirical studies were excluded from consideration for this study. The findings showed that the environmental factor was the primary factor for learners' poor OECS performance in EFL contexts. For the method of teaching and assessment of learners' OECSs, the use of technology is rapidly increasing in different EFL contexts. This study suggests some implications for both future researchers and academics for developing EFL learners' oral English communication skills dealing with environmental, psychological, and linguistic factors along with teaching and learning resources at the tertiary level in EFL contexts.
\end{abstract}

Keywords: oral English communication skills, EFL learners' problems, teaching method, assessment method, systematic literature review

\section{Introduction}

For EFL (English as a Foreign Language) learners, gaining mastery over oral English communication skills is always more challenging than other language skills like reading, listening, and writing. In the Fourth Industrial Revolution era, the demand for oral English communication skills is inevitably increased for the use of IoT as a means of communication globally. The word 'communication' originated from the Latin word 'communicare' (meaning to share), and the French word 'communis' (common) means one's experience sharing with others (Okoro, 2007). Oliver and Philp (2014) defined oral communication as "the speaking and listening that occurs in real-time (i.e., in the present) in communicative exchanges (i.e., interactions)" (p. 5). This kind of exchange depends on the process of meaning-making and understanding of both communicators (Adler \& Rodman, 2009). The significance of oral communication skills in mastering a second language was accentuated by Ellis (2003) when he highlighted that second and foreign language acquisition encompasses the ability to use the sound and grammar systems to communicate meanings. Oral communication skills make face-to-face interactions possible, as well as long-distance interactions such as online conversations.

In this techno-drenched world, for maintaining online and offline communication, EFL learners need to be skilled in oral communication including various vital aspects. In today's global context, they often need oral English communication skills for expressing opinions, making arguments, offering explanations, transmitting information, and making impressions upon others in their personal lives, future workplaces, social interactions, and political endeavors (Rahman, 2010).

Moreover, it has become an aphorism in EFL contexts that a graduate with a good command of oral English communication skills has a better opportunity in their professional life than one who does not (Idrus, 2016; 
Kunioshi, Noguchi, Hayashi, \& Tojo, 2012). Hence, preparing for the competitive and explosive nature of market value in both EFL and native contexts, graduates need to improve their skills (Subramaniam \& Harun, 2012). Moreover, OECSs require distinct attention for learning and teaching in education programs for all disciplines so that students could be operative in both their academic and professional lives (Kunioshi et al., 2012; Malthus \& Lu, 2012; Mitchell \& Eng, 2010; Nikolic et al., 2018; Tuomaitè \& Zajankauskaitė, 2017).

However, globalization increasingly demands the scholarly use of English for multiple purposes (Jim, 2018). Despite the importance of OECSs in the EFL contexts, tertiary-level learners' oral performance is not up to the mark, and in some cases it is still incomprehensible (Afshar \& Asakereh, 2016). Studies have pointed out a number of factors that are responsible for developing learners' OECSs performance in the EFL context(Chen \& Goh, 2011; Fitria \& Salwa, 2018; Sinwongsuwat, \& Bojanić, 2015; Soomro et al., 2019). Other studies employed different teaching and assessment methods for bringing innovation to existing traditional teaching and assessment methods in different EFL contexts for improving tertiary level learners' oral skills (Darmi \& Albion, 2017; Lana et al., 2018)

Thus, the objectives of this systematic literature review (SLR) critically presents an overview of the factors responsible for the poor oral performance of EFL learners and the methods for teaching and assessing oral English communication skills at the tertiary level in EFL contexts from published empirical studies from 2010 to 2019 while maintaining the principles of the PRISMA model as inclusion and exclusion criteria of the studies. The significance of this SLR study is to present different issues like common problems, teaching strategies, and assessment methods for developing learners' OECSs in EFL contexts. This study could also provide insights for EFL policymakers, teachers, and educators to help their learners improve by provising an overview of the findings of this study for redesigning oral English communication pedagogy for future EFL contexts.

The researchers set the following research questions for this systematic literature review:

1. What are the factors responsible for EFL learners' poor oral English communication skills performance?

2. What are the teaching methods employed for developing learners' oral English communication skills in EFL contexts?

3. What types of assessment methods are employed for developing learners' oral English communication skills in EFL contexts?

\section{Materials and Methods}

\section{Literature Search}

Reputable online databases such as SpringerLink, Scopus, Web of Science, and Google Scholar from 2010 through December 2019 were queried for studies addressing the teaching and learning of oral English communication skills in EFL contexts. All articles published in native English-speaking countries, those with non-empirical or anonymous contexts, and articles written earlier than 2010 were excluded. We included articles related to oral skills, oral communication skills, and oral English communication skills teaching and learning. Search terms were the phrases "oral communication skills" and "oral English communication skills." For only the Google Scholar database, the phrases were kept within an inverted comma for identifying topic related to literature. The Preferred Reporting Items for Systematic reviews and Meta-Analyses (PRISMA) guidelines were followed (Moher et al., 2009) for selecting more relevant research studies on the topic and sorting for scrutiny was done with NVIVO for developing themes systematically on the issues for this study.

\section{Selection of Articles}

A PRISMA flow diagram for the search and inclusion/exclusion process is presented in Figure 1. A total of 2907 titles and/or abstracts assembled from the databases were reviewed by the researchers and 2782 articles were excluded, as they did not address any of the research questions after being screened by their titles. The remaining 125 were checked for duplicity resulting in 99 useable articles. For finding the most relevant articles to the SLR questions for full review, the studies such as reviews, conceptual articles, and those that were conducted in native contexts were excluded from the consideration of the analysis. Finally, 51 studies met the 
criteria of this SLR for quality of evidence and pertinence to the research questions. Some articles were analyzed for multiple questions.

\section{Figure 1}

PRISMA flow diagram

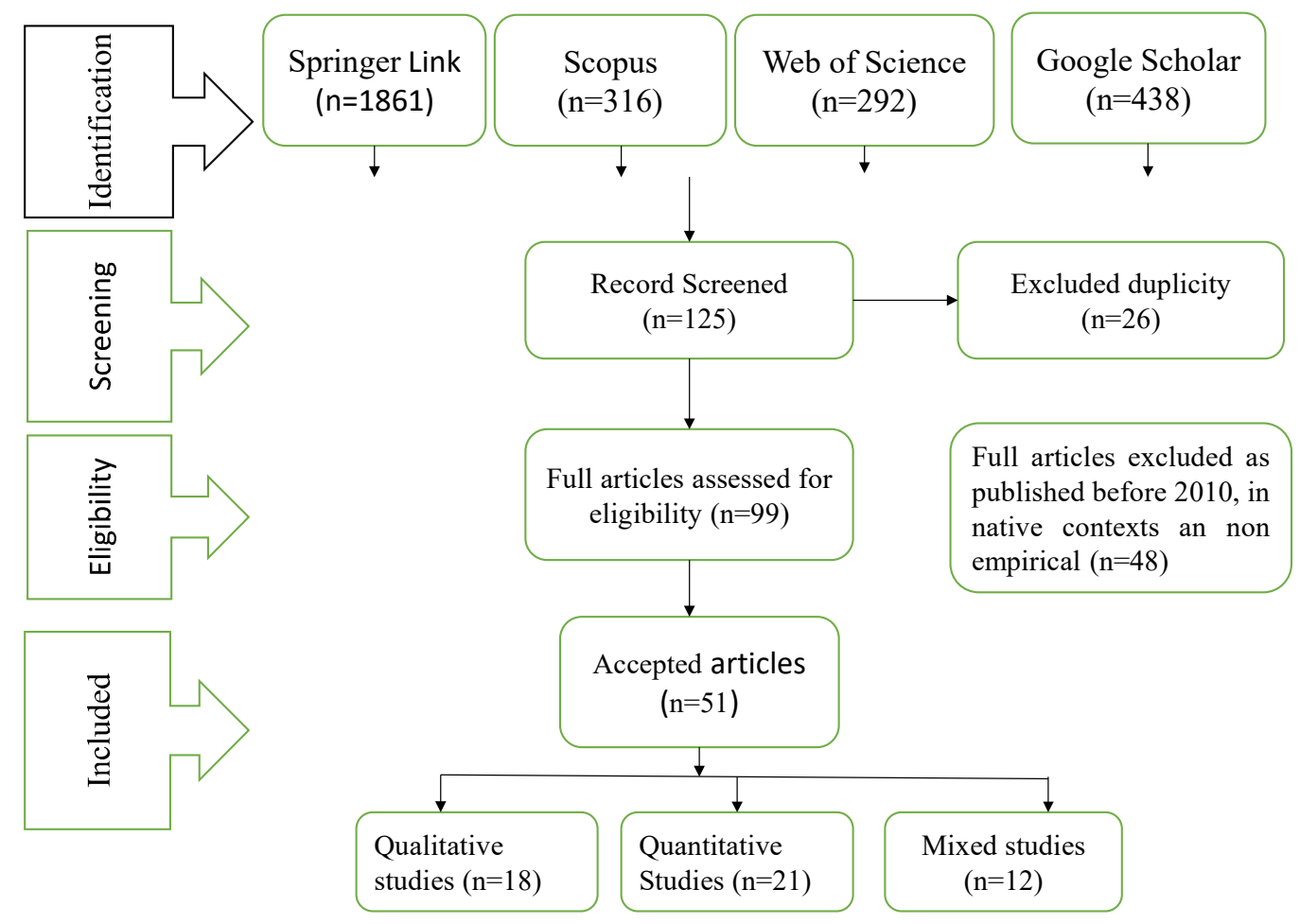

\section{Preparing Phase}

The preparation phases of the analysis comprised all the processes necessary for the analysis (Figure 2). In the pre-analysis phase, Mendeley was used for making references database for all the primary studies $(n=50)$. From the Mendeley, all the articles were exported as .ris files to import into NVIVO 12 software. The imported articles were classified for ensuring the targeted year of publication and EFL contexts with NVIVO. Then, pre-codes were developed as primary nodes in NVIVO 12 for learners' poor performance and teaching and assessment methods. Under the primary nodes, sub-nodes were built to get a scrutinized analysis of the texts. These nodes and sub-nodes were the answers to the SLR questions.

\section{Figure 2}

Preparing phases of the analysis

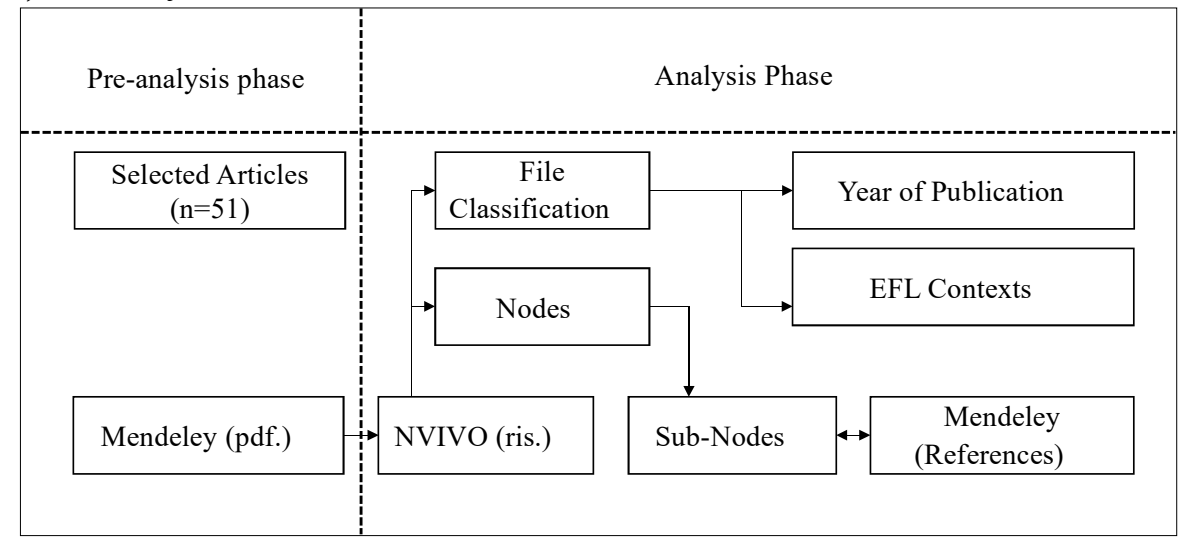




\section{Analysis Phase}

All the selected articles conducted in EFL contexts (Figure 3) were prepared for thematic analysis using the NVIVO program for finding out the answers to the SLR questions. NVIVO is a software program that provides tools for analyzing qualitative data in qualitative or mixed-method research. Thematic analysis was used to categorize facts for uncovering meaning (Fereday \& Muir-Cochrane, 2006). In this study, thematic analysis was used to analyse texts for identifying themes pertaining to factors causing learners' poor performance, teaching strategies, and assessment methods for developing learners' OECS performance in EFL contexts. Researchers believe that if EFL teachers and practitioners understand the factors causing learners' poor oral performance, effective teaching strategies, and assessment methods they could concentrate more on developing learners' oral skills efficiently. Therefore, the SLR is considered indispensable for reviewing all of the related articles thoroughly and investigating the gathered data via thematic analysis. Consequently, from the SLR questions, three concepts, such as factors causing learners' poor performance, teaching strategies, and assessment methods, were selected as the major themes.Under these themes, there were sub-themes developed such as learners' passiveness, limited oral practice, learners' mixed abilities, and large class sizes for environmental factors; shyness, confidence, anxiety, and emotions for psychological factors; accuracy, fluency, pronunciation, low vocabulary levels, and lack of language knowledge for linguistic factors; and teachers' low efficacy and lack of teaching resources for teaching resources factors. Similarly, under the theme of teaching methods, technology-based, task-based, interactive, microteaching and communicative methods were developed as subthemes. Finally, for the assessment method, mobile-based, university-based, teacher-based, and mixed-panel assessment methods were developed as sub-themes. These themes and sub-themes guided the researchers to reach the objectives of this study.

\section{Figure 3}

EFL contexts of the studies

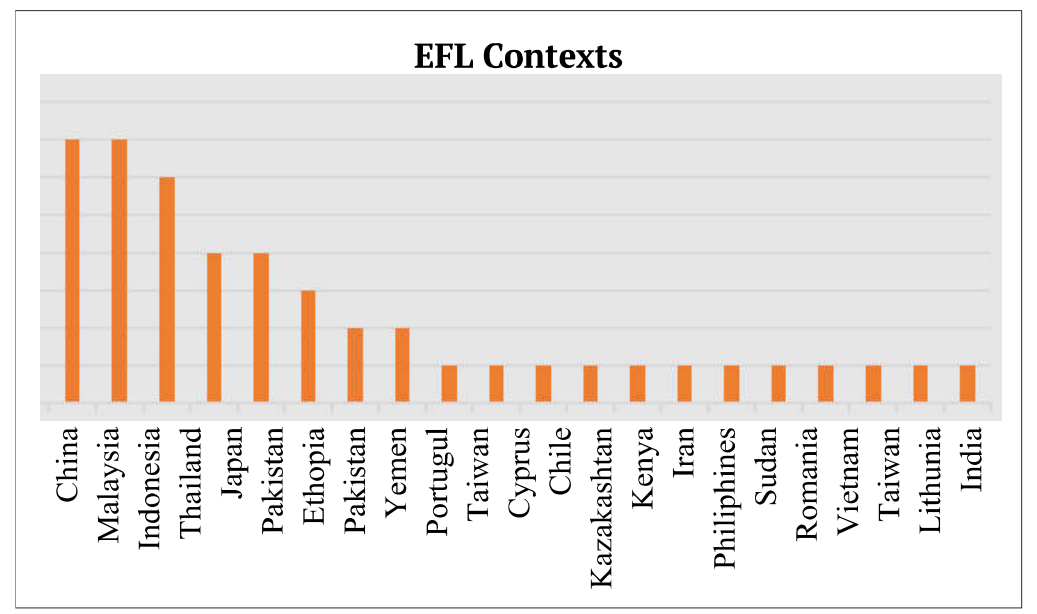

\section{Results and Discussion}

This section illustrates the detailed answers to the SLR questions for this review. The researchers identified the factors that were responsible for EFL learners' poor performance in oral English communication, teaching, and assessment techniques for developing oral skills in EFL contexts from the previous studies. The final section offers a discussion on insights for dealing with these problems, introducing teaching and assessment techniques for developing learners' oral English communication skills in EFL contexts.

\section{Factors for EFL Learners' Poor Oral English Communication Skills}

Based on the analysis of the studies, the results of the first research question are presented in Figure 4. Of the 51 studies, 34 studies reported different factors that were responsible for developing learners' oral skills. The hierarchy chart showed that there were four different factors, e.g., environmental $(n=14)$, psychological $(n=11)$, linguistic $(n=9)$, and teaching resources $(n=2)$ influencing the development of 
learners' oral skills at the tertiary level in EFL contexts. The majority of the studies stated that environmental factors were the prime cause of EFL learners' oral skills developing. On the other hand, the fewest number of studies reported that the teaching resources factor was the significant factor for EFL learners' oral skills development at the tertiary level.Other studies reported more than one factor. Some of the sub-factors will be discussed below

\section{Figure 4}

Hierarchy chart of the factors
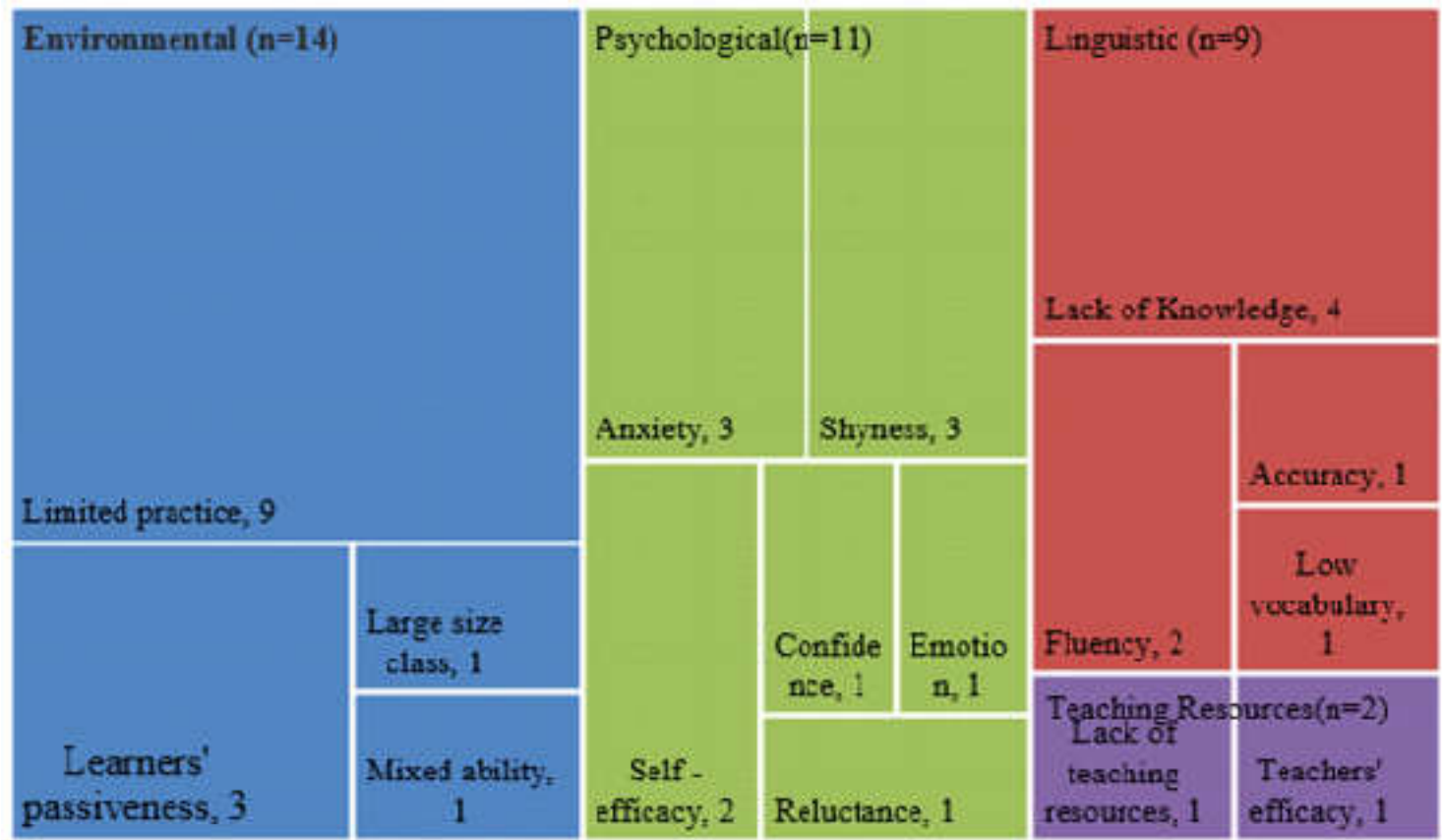

\section{Environmental Factors}

Environmental factors refer to the nature of non-native learning and teaching settings. The findings showed there were four different types of environmental factors: limited oral practice environment $(n=9)$, learner passiveness $(n=3)$, large class sizes $(n=1)$, and learners' mixed abilities $(n=1)$. Most of the studies illustrated that limited opportunities to practice oral skills inside and outside the classroom were the prime environmental factor for the poor development of EFL learners' oral skills in EFL contexts (Aeni et al., 2017; Alam \& Uddin, 2013; Ella \& Dapudong, 2014; Fitria \& Salwa, 2018; Ismail et al., 2018; Rahman, 2010). As there was a lack of an oral practice environment in EFL contexts, learners rarely got the opportunity to practice outside the classroom (Soomro et al., 2019).

The findings showed that the traditional lecture-based teaching method still existed in the EFL contexts for teaching oral skills. In this method, learners played passive roles in their lessons and this hindered them from developing oral communication skills (Abid, 2018; Bruner et al., 2015). Moreover, the findings also showed that EFL learners were not motivated to learn oral skills. EFL learners' mixed abilities and inadequate educational backgrounds were also responsible for their poor performance (Bruner et al., 2015; Soomro et al., 2019). In an EFL class, there were different levels of learners, e.g., low, mid, and high. Whereas low-level learners tried hard and lost interest in the end, high-level learners developed quickly and received more attention. The last environmental factor was large class sizes (Chen \& Goh, 2011). Large class sizes were a common phenomenon in many EFL contexts. In the large classes, it was difficult for the teacher to manage all the learners for engaging in oral tasks.

Under environmental factors, learners' limited practice, learners' passiveness, learners' mixed abilities, and large class sizes were found to be major causes of poor performance in EFL contexts. Other environmental factors like the influence of L1 on OECSs and learners' exposure to OECSs outside the classroom were unexplored. 


\section{Psychological Factors}

The results showed that there were six types of psychological factors, e.g., anxiety $(n=3)$, shyness $(n=3)$, selfefficacy $(n=2)$, confidence $(n=1)$, emotions $(n=1)$, and reluctance $(n=1)$, that were responsible for causing EFL learners' poor OECSs in EFL contexts. Both anxiety and shyness were equally addressed in these studies. Some studies suggested that anxiety was a crucial psychological factor that led to learners' disruption, sweating, and trembling while they were speaking. These were due to a lack of practice inside and outside the classroom, insufficient vocabulary, low L2 motivation, and fear of criticism (Aeni et al., 2017; Kasbi \& Shirvan, 2017; MacWhinnie \& Mitchell, 2017).For developing oral skills, learners' shyness that resulting from nervousness, inferiority complexes, and having a fear of doing something wrong, was one of the major psychological factors in EFL contexts (Aeni et al., 2017; Alam \& Uddin, 2013). The findings also showed that EFL learners' lack of confidence, resulting from a lack of oral practice and linguistic knowledge, was another challenging factor for oral skills learning (Fitria \& Salwa, 2018).

According to the results, the emotional factor was another psychological factor that emerged from lack of emotional support from teachers, family members, and friends. The emotional factor influenced female learners more than male learners in Kazakhstan (Ismail et al., 2018). Additionally, self-efficacy was another psychological factor related to learners' aptitudes, attitudes, and aspirations that influenced learners' oral skill development (Idrus et al., 2011).Finally, the results showed that learners' reluctance to speak in English emerged from a lack of confidence for learning oral skills in EFL contexts (Şimon, 2014). All these psychological factors contributed to learners' nervousness when they are communicating using oral skills.

Regarding psychological factors, this study found learners' shyness, anxiety, self-efficacy, reluctance, emotions, and confidence rather than motivation, nervousness, and fear to speak from the previous studies. The findings would suggest that more studies need to be addressed in this regard for developing learners' OECSs.

\section{Linguistic Factors}

The results revealed that there were four different types of linguistic factors, e.g., lack of language knowledge $(n=4)$, accuracy $(n=1)$, fluency $(n=2)$, and low vocabulary $(n=1)$ were responsible for causing EFL learners' poor OECSs in EFL contexts. According to the results, learners' lack of grammatical knowledge was prominent. When learners spoke, they made mistakes using improper grammar (Chen \& Goh, 2011; Soomro et al., 2019; Zukurnain \& Kaur, 2014). The other linguistic factor related to accuracy revealed that learners were unable to produce accurate speech in terms of pronunciation, presentation, and communicating ideas (Alghail \& Mahfoodh, 2019). Fluency was a linguistic factor related to speech rate, spontaneity, and frequency of pauses that was also responsible for EFL learners' poor oral skills (Alghail \& Mahfoodh, 2019; Onoda, 2014). Finally, EFL learners' low vocabulary level was another linguistic factor for hindering the developing oral skills performance (Soomro et al., 2019).

Thus, the findings showed that the lack of language knowledge, fluency, accuracy, pronunciation and vocabulary were linguistic problems for developing learners' oral skills. But learners' problems related to the suprasegmental features of speech, especially stress and intonation, were not found. Therefore, the findings of this study would recommend more studies addressing these issues in future research.

\section{Teaching Resources}

According to the results, a lack of teaching resources was also a challenging factor for developing learners' oral skills at the tertiary level in EFL contexts. The findings reported that teaching resources were related to the lack of teaching materials and teachers' efficacy. A lack of teaching materials indicated that textbooks were not appropriate for developing learners' oral skills. Moreover, in EFL contexts, there was a lack of audio-video laboratories and multimedia equipment for teaching-learning oral skills. On the other hand, teachers had low efficacy as they had a deficiency in oral skills and pedagogical knowledge for developing learners' oral skills in EFL contexts (Chen \& Goh, 2011). In some cases, both learners' and teachers' low efficacy was also responsible for poor development in learners' oral skills in EFL contexts (Idrus et al., 2013).

However, some of the other problems related to teaching resources factors, e.g. the curriculum, lesson plans, and oral lesson activities were not addressed. Thus, this study would suggest focusing on these issues in the future. 


\section{Teaching Methods}

Based on the analysis of the studies, the results of the second research question are presented in Figure 5. Of the 51 studies, 18 studies reported five different types of teaching methods e.g., technology-based $(n=9)$, taskbased $(n=7)$, communicative $(n=1)$, interactive $(n=1)$, and microteaching $(n=1)$ employed for developing learners' oral skills in different EFL contexts. The findings showed that bringing innovation into traditional teaching methods for creating a new environment for oral practice inside and outside the classroom was essential for developing learners' oral skills (Bunjan \& Suppasetseree, 2017; Darmi \& Albion, 2017; Subramaniam et al., 2013).

According to the results, the highest number of studies used different types of technology e.g., online-based $(n=3)$, tablet $(n=1)$, Skype $(n=1)$, YouTube $(n=1)$, and mobile $(n=1)$ as a teaching tool for developing learners' oral skills. The study found that technology from audiobooks to language apps helped develop oral skills through gaining correct pronunciation and the correct use of words in EFL contexts (Lana et al., 2018). The largest number of studies used online-based teaching methods that supported the virtual language community, which helped to develop learners' oral skills (Bunjan \& Suppasetseree, 2017; Hart, 2016; Kunioshi et al., 2012). According to Darmi and Albion (2017), classes that employed mobile-based learning had significant improvement in enhancing OECSs in Malaysian contexts.

Using tablets in ELT teaching in the Portuguese context, iBook and other educational resources assisted learners in improving oral skills (Couvaneiro \& Pedro, 2015). Integrating Skype with teaching methodologies was found to be very effective and useful for reducing learner anxiety when attempting to develop oral skills (Herlo et al., 2017). Moreover, the inclusion of YouTube into the classroom made learners active participants for learning OECSs (Subramaniam et al., 2013).

\section{Figure 5}

Hierarchy chart of teaching method

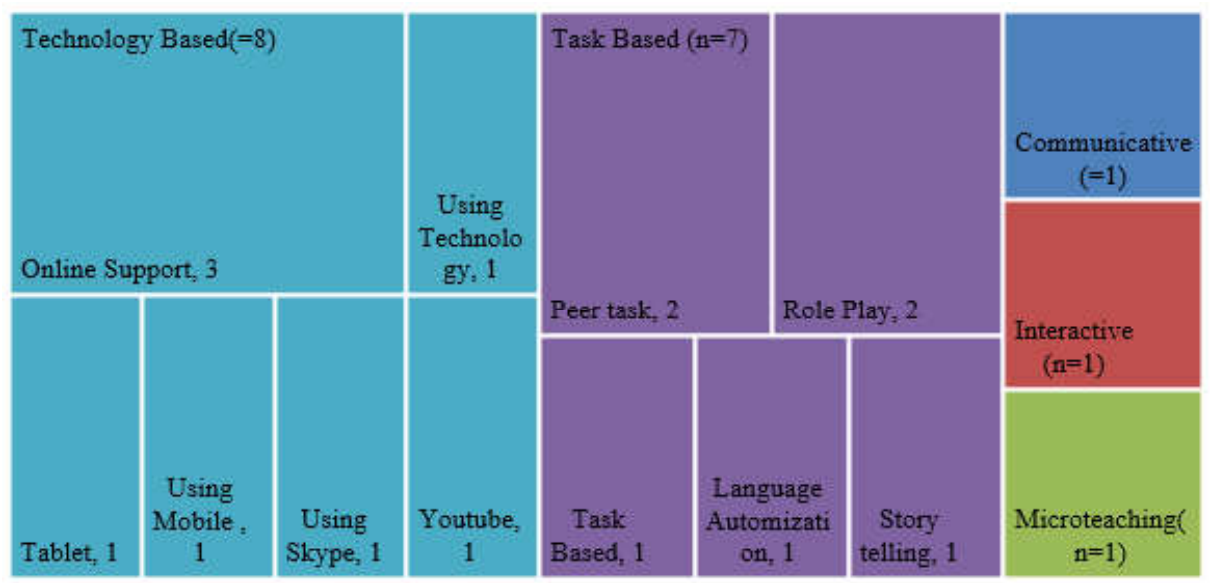

According to the results, there were five different types of task-based teaching methods, e.g., peer tasks ( $\mathrm{n}=2)$, role play $(n=2)$, tasks-based $(n=1)$, language atomization $(n=1)$, and storytelling task-based $(n=1)$ found in different EFL contexts. Rahman (2010) reported that the task-based approach through involving learners in different tasks simulating real-life situations assisted EFL learners in enhancing their OECSs. The findings revealed that task-based teaching with peer-mediated strategies helped to develop learners' OECSs in different EFL contexts (Mamo et al., 2015; Tsai, 2019). The role-play teaching method also had a significant impact on increasing learners' motivation and confidence for developing OECSs (Nasihah, 2019; Tipmontree \& Tasanameelarp, 2018). The findings showed that the storytelling task-based teaching method was found useful for the development of adult learners' oral communication skills in the Nepalese context. (Manzano, 2018).

The results also showed some other teaching methods were used to develop learners' OECSs in different contexts. For example, the communicative teaching method $(n=1)$ was found effective for enhancing EFL 
learners' OECSs. In the Malaysian context, Zukurnain and Kaur (2014) reported that a communication strategy that promotes spontaneity between speakers to help them agree on meaning in the target language could help them overcome the challenges faced by learners when learning OECSs. By developing communicative strategies, EFL learners gained oral competence (Thu et al., 2016).In the context of Kenya, the interactive teaching method $(n=1)$ used by EFL teachers for providing opportunities for language use, accuracy, proficiency, and immediate feedback had a positive impact on learners' OECSs performance (Jessica et al., 2015). In the context of Chile, microteaching $(n=1)$, which engaged learners actively in the learning session, had an influential impact on learners' oral skills development (Herrera \& Vielma, 2018).

From the results of this study, there were five different teaching methods found: technology-based, task-based, microteaching, interactive, and communicative teaching. Although the results illustrated that the trend of using technology in teaching and learning OECSs in EFL contexts is rapidly increasing, there is still a lack of evidence for a solid theoretical framework in this regard. There are very few studies that dealt with the specific problems of learners' OECSs development using technology. Moreover, there is a need for research into which technology is suitable for OECS teaching and learning in EFL contexts.

\section{Assessment Methods}

The results of data analysis for the third research question showed four different types of assessment methods $(n=4)$ that were used to evaluate learners' oral English communication skills in different EFL contexts. They are presented in Figure 6. They were university-based speaking assessment $(n=2)$, teacher feedback $(n=2)$, mobilebased feedback $(n=1)$, and a mixed panel assessment method $(n=1)$.

\section{Figure 6}

\section{Assessment methods}

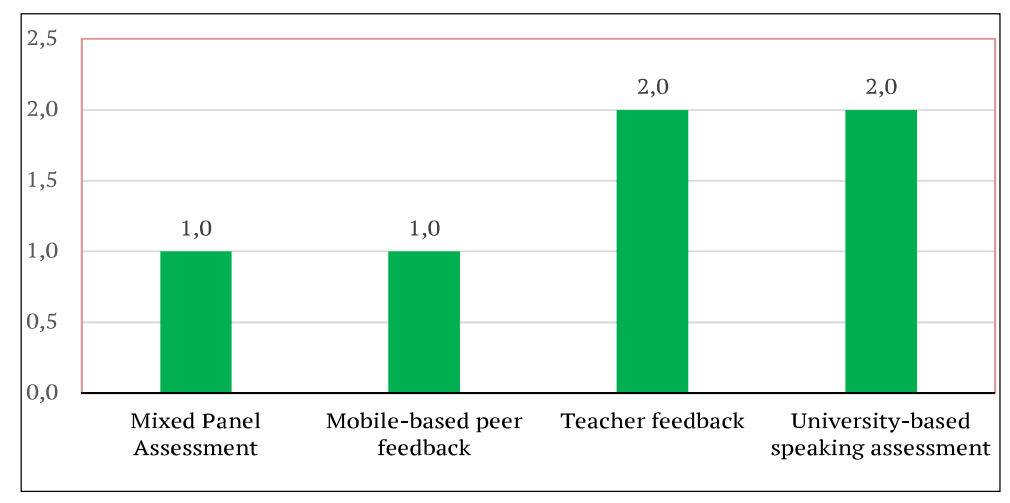

The findings illustrated that mobile-based feedback monitored learners' oral production and the learners received corrective feedback that enhanced their overall communication performance (Fang, Cassim, Hsu, \& Chen, 2018). Another study reported that teacher-based feedback, which involved the "praisecriticism suggestion” supported the development of learners' OECSs performance (Mulualem et al., 2019; Wang et al., 2017, 2018).In some EFL contexts, like in Indonesia, teacher feedback boosted learners' oral skills development (Saefurrohman, 2018). Kernel et al., (2017) reported in their study that mixed panel assessment prepared students for life after university through multidisciplinary thinking. It also provided self-assessment in which learners understood their mistakes for future use. In the context of mainland China, a university-based assessment was useful for eliciting candidate's oral performances. At the same time, it also revealed that oral features, e.g., length of turns, choice of words, hesitation markers, and topic coherence, had the potential to affect the scores of the candidate (Liu \& Jia, 2017). Moreover, Gan, Oon, and Davison (2017) reported that instituition-based assessment made a significant change in developing learners' oral skills since learners were familiar with it.

The findings showed that there were few studies found on assessment methods for the evaluation of EFL learners' OECSs performance. These methods were university-based assessment, teacher feedback, mobilebased, the mixed panel assessment methods. This study suggests that more studies are needed on the assessment method to facilitate learners' oral performance. 


\section{Limitations and Implications}

We reviewed and analyzed empirical studies on the issues surrounding the development of oral skills in EFL contexts e.g., problems of EFL learners, and teaching and assessment methods, published in the reputable online databases of SpringerLink, SCOPUS, Web of Science, and Google Scholar from 2010 to 2019. Based on the analysis, there are four main problems that are responsible for EFL learners' poor oral English communication skills, namely environmental, psychological, linguistic, and teaching resource issues. Although this study found four main problems, there are other problems such as the role of learners' L1, motivation, nervousness, stress, intonation, oral activities, lack of authentic materials, and the curriculum that are also responsible for EFL learners' oral skills development in EFL contexts but were less studied. This study has further found that the previous studies dealt with the lack of teachers' efficacy but no evidence was found regarding learners' efficacy as a barrier for EFL learners' OECSs development. This SLR also found that there is a lack of evidence on how these problems are solved for developing learners' OECSs in EFL contexts.

This study also revealed that the integration of technology into teaching methods had a significant impact on developing EFL learners' oral skills in EFL contexts. But there is still a lack of studies on the theoretical perspective of using technology for teaching oral skills in EFL contexts. Moreover, there is still a debate over which technology is more effective for teaching oral skills in EFL contexts. Finally, this study reported that there are few studies conducted on assessment methods for evaluating EFL learners' oral skills. Thus, this study suggests that it is time to think about how technology can be used effectively to develop EFL learners' OECS in EFL contexts since the world is now experiencing the Fourth Industrial Revolution.

Therefore, the findings of this analysis provide a critical and current overview of teaching and learning oral skills for practical implications for teachers, policymakers, and researchers. We anticipate that the identified problems and methods could provide insights for academics and practitioners for overcoming the challenges developing learners' OECSs in EFL contexts.Moreover, the findings of this study suggest that more empirical studies are needed to find ways to deal with these problems developing learners' OECSs in EFL contexts. For developing learners' OECS skills, there is a need to innovate oral skills teaching and assessment methods. Thus, these findings could extend the body of knowledge on language teaching, providing an overview of accumulating issues like problems and methods for developing EFL learners' oral English communication skills in EFL contexts.

\section{Conclusion}

Teaching and learning oral English communication skills in an EFL context is a problematic phenomenon for both teachers and learners. It would be an overstatement to say that EFL learners' OECS performance at the tertiary level in the EFL context is up to the mark after their graduation. This systematic literature review accumulated the factors responsible for EFL learners' poor OECSs in different EFL contexts. It also shined a light on the existing scenario for teaching and assessing methods of OECSs in EFL contexts employed in studies from 2010 to 2019. However, the past research on the factors leading to learners' poor performance and the methodfs for the teaching and learning of oral English communication skills in EFL contexts are scattered and haphazard.

The findings showed that the environmental factor was the primary factor, along with other factors impacting EFL learners' poor OECS performance in EFL contexts. The environmental factors entailed learners' passiveness, demotivation, mixed abilities, and large class sizes. The psychological factors entailed learners' anxiety, shyness, self-efficacy, confidence, emotions, and reluctance.Again, linguistics factors were related to learners' lack of language knowledge, accuracy, fluency, and low vocabulary levels, whereas a lack of teaching resources along with the lack of authentic materials for teaching and learning oral skills were also an important finding of this study for future researchers. Previous studies showed that these factors were explicitly or implicitly responsible for EFL learners' poor oral performance.

The findings further illustrated five different types of teaching methods, e.g., technology-based, task-based, communicative, interactive, and microteaching, employed for developing learners' oral skills in different EFL contexts. For the method of teaching learners' OECSs, the use of technology is rapidly increasing in different 
EFL contexts. Hence, the pedagogical establishment of using technology for teaching and learning oral skills should be focused on. Furthermore, this study found four different methods of assessment of oral skills: university-based speaking assessment, teacher feedback, mobile-based feedback, and mixed panel assessment.

For developing EFL learners' OECS performance, more empirical studies are needed to address these factors for solutions and innovative teaching and assessment methods. Thus, this study provides insights based on the discussion of the selected studies for enhancing learners' oral English communication skills. As OECSs are important for EFL learners, this study provides a potential foundation for researchers to conduct and implement more research for dealing with the factors responsible for EFL learners' poor OECS performance. Nevertheless, the findings suggest that these factors and methods of teaching and assessment are interrelated for teaching and learning oral communication skills in EFL contexts. Further studies are needed for integrating and innovating teaching and assessment methods with the assistance of technology for dealing with the barriers affecting the development of EFL learners' oral communication skills in EFL contexts.

\section{References}

Abid. (2018). Indonesian pre-service english teachers' perceived challenges in improving English oral communication skills. Journal of English Education and Linguistics Studies, 5(2), 147-170. https://doi.org/ https://doi.org/10.30762/jeels.v5i2.716

Aeni, N., Jabu, B., Rahman, M. A., \& Strid, J. E. (2017). English oral communication apprehension in students of Indonesian maritime. International Journal of English Linguistics, 7(4), 158-165. https://doi.org/10.5539/ijel. v7n4p158

Afshar, H. S., \& Asakereh, A. (2016). Speaking skills problems encountered by Iranian EFL freshmen and seniors from their own and their English instructors' perspectives. Electronic Journal of Foreign Language Teaching, 13(1), 112-130. https://e-flt.nus.edu.sg/v13n12016/afshar.pdf

Alam, Q., \& Uddin, A. B. (2013). Improving English oral-communication skills of Pakistani public schools students. International Journal of English Language Teaching, 1(2), 17-36.

Alghail, A. A. A., \& Mahfoodh, O. H. A. (2019). Academic oral communication difficulties encountered by yemeni postgraduate students in a Malaysian university. Issues in Educational Research, 29(2), 301-325.

Bruner, D. A., Sinwongsuwat, K., Bojanić, B., \& Radić-Bojanić, B. (2015). EFL oral communication teaching practices: A close look at university teachers and A2 students' perspectives in Thailand and a critical eye from Serbia. English Language Teaching, 8(1), 11-20. https://doi.org/10.5539/elt.v8n1p11

Bunjan, A., \& Suppasetseree, S. (2017). The video blog based role play lessons to enhance English oral communication skills for tourism students. International Journal of Educational Administration, 9(1), 1-16.

Chen, Z., \& Goh, C. (2011). Teaching oral English in higher education: Challenges to EFL teachers. Teaching in Higher Education, 16(3), 333-345. https://doi.org/10.1080/13562517.2010.546527

Couvaneiro, S.R., \& Pedro, N. (2015). Collaborative learning using tablets in EFL to develop oral communication. In ACM International Conference Proceeding Series (pp.139-143).ACM. https://doi.org/10.1145/2808580.2808602

Darmi, R., \& Albion, Peter R. (2017). Enhancing oral communication skills using mobile phones among undergraduate English language learners in Malaysia. In J. H. Murphy A., Farley H., Dyson L. (Eds.), Mobile learning in higher education in the Asia- Pacific Region education (Vol. 40, I pp. 359-375). Springer Singapore. https://doi.org/10.1007/978-981-10-4944-6

Ella, R. B., \& Dapudong, R. C. (2014). Oral communication achievement of the Bachelor of Arts students major in English at Rajamangala University of Technology, Lanna, Thailand. International Journal of Academic Research in Progressive Education and Development, 3(4), 209-224. https://doi.org/10.6007/ijarped/v3-i4/1252

Fang, W.-C., Cassim, F. A. K., Hsu, C.-N., \& Chen, N.-S. (2018). Effects of reciprocal peer feedback on EFL learners' communication strategy use and oral communication performance. Smart Learning Environments, 5(1). https://doi.org/10.1186/s40561-018-0061-2

Fereday, J., \& Muir-Cochrane, E. (2006). Demonstrating rigor using thematic analysis: A hybrid approach of inductive and deductive coding and theme development. International Journal of Qualitative Methods, 5(1), 80-92. https://doi.org/10.1177/160940690600500107

Fitria, R., \& Salwa. (2018). Students ' perceptions of English oral communication usage during practice learning program. Inovish Journal, 3(2), 155-162.

Gan, Z., Oon, E. P. T., \& Davison, C. (2017). ESL students' oral performance in English language schoolbased assessment: Results of an empirical study. Language Testing in Asia, 7(1). https://doi.org/10.1186/ 
s40468-017-0051-2Hart, T. (2016). Learning how to speak like a "native": Speech and culture in an online communication training program. Journal of Business and Technical Communication, 30(3), 285-321. https:// doi.org/10.1177/1050651916636363

Herlo, D., \& Kurt, M. (2017). Improve your oral communication skills in English by using informal synchronous chat. Paper Presentae at The 7th International Social \& Behavioural Sciences EInternational Conference.

Herrera, R. F., \& Vielma, J. C. (2018). Impact of microteaching on engineering students' communication skills. International Journal OfEngineering Education, 34(6), 1768-1777.

Idrus, H. (2016). Enhancing oral presentation skills of ESL students: The use of oral communication strategies. In S. Fun Tang, \& L. Logonnathan (Eds.), Assessment for learning within and beyond the classroom (pp. 437446). Springer. https://doi.org/10.1007/978-981-10-0908-2

Idrus, H., Salleh, R., \& Muhammad, R. L. T. (2011). Oral communication ability in English: An essential skill for engineering graduates. Asia Pacific Journal of Educators and Education, 26(1), 107-123.

Idrus, H., Salleh, R., Wan Hassan, W.N., \& Ali, R.M.M.(2013). Self-efficacy in English language oral communication skills of technical trainees. In The Proceedings of 2013 IEEE International Conference on Teaching, Assessment and Learning for Engineering (pp. 800-804). https://doi.org/10.1109/TALE.2013.6654548

Ismail, K., Tuspekova, A., \& Mustaffa, R. (2018). English oral communication in public secondary schools in Kazakhstan: Understanding its practice and challenges. 3L: Language, Linguistics, Literature, 24(2), 122-126. https://doi.org/10.17576/3L-2018-2402-09

Jessica, M. M., Kemboi, G. C., \& Andiema, N. C. (2015). A study on interactive teaching methods in developing oral communicative competence in learners of English language in Trans Nzoia West, District of Kenya. International Invention Journal of Arts and Social Sciences, 2(1), 5-13.

Jim,C.Y.H.(2018).Contexts, problems and solutions in international communication: Insights for teaching english as a Lingua Franca. Journal of Asia TEFL, 15(2), 257-275. https://doi.org/10.18823/asiatefl.2018.15.2.1.257

Kasbi, S. and, \& Shirvan, E. M. (2017). Ecological understanding of foreign language speaking anxiety: Emerging patterns and dynamic systems. Asian-Pacific Journal of Second and Foreign Language Education, 2(1). https:// doi.org/10.1186/s40862-017-0026-y

Kernec, JL. Levrai , P., \& Bolster, A. (2017). Bringing the outside world in: Using mixed panel assessment of oral presentations with Electrical and Electronic Engineering students. Proceedings of 2016 IEEE International Conference on Teaching, Assessment and Learning for Engineering (pp. 1-8). IEEE. https://doi.org/10.1109/ TALE.2016.7851761

Kunioshi, N., Noguchi, J., Hayashi, H., \& Tojo, K. (2012). An online support site for preparation of oral presentations in science and engineering. European Journal of Engineering Education, 37(6), 600-608. https:// doi.org/10.1080/03043797.2012.733681

Lana, H., Shehata, A., \& Omer, M. A. E. (2018). Effective techniques used by teachers to improve English oral communication skills in sudanese secondary schools. International Journal of Information Research and Review, 05(II), 5899-5909.

Liu, L., \& Jia, G. (2017). Looking beyond scores: Validating a CEFR-based university speaking assessment in Mainland China. Language Testing in Asia, 7(1), Article 2. https://doi.org/10.1186/s40468-017-0034-3

MacWhinnie, S. G. B., \& Mitchell, C. (2017). English classroom reforms in Japan: A study of Japanese university EFL student anxiety and motivation. Asian-Pacific Journal of Second and Foreign Language Education, 2(1), Article 7. https://doi.org/10.1186/s40862-017-0030-2

Malthus, C., \& Lu, H. (2012). "Not a Mission Impossible": The perceptions of successful graduates on the development of spoken English for the workplace. Journal of Asian Pacific Communication, 22(1), 120-139. https://doi.org/10.1075/japc.22.1.07mal

Mamo, B., \& Yigzaw, A. (2015). Fidelity of peer mediation and its role in improving students' oral English communication skills. Science, Technology and Arts Research Journal, 4(1), 215-217. https://doi.org/10.1016/ S0002-9394(26)91015-5

Manzano, B.A. (2018). Examining the oral communication strategies used by a group of nepalese adult learners in an ESL context. 3L: Language, Linguistics, Literature, 24(1), 84-96. https://doi.org/10.17576/3L-2018-2401-07

Mitchell, R., \& Eng, T. L. (2010). Assessment of students' learning experience in an oral communication course at MIT for EECS majors. In 2010 IEEE Frontiers in Education Conference (FIE), F1F-1-F1F-5. https://doi. org/10.1109/FIE.2010.5673341

Moher, D., Liberati, A., Tetzlaff, J., \& Altman, D. G. (2009). Preferred reporting items for systematic reviews and metaanalyses: The PRISMA statement. PLoS Medicine, 6(7), e1000097. https://doi.org/10.1371/journal.pmed.1000097

Mulualem, Muchie, M., \& Meles, Y. (2019). Assessing teachers' practices and challenges of teaching students' oral communication skills. International Journal of Research in Social Sciences and Humanities, 9(II), 237-246. 
Nasihah, M. (2019). The use of role play technique to improve students' english oral communication. Journal of English for Academic and Specific Purposes, 2(1), 10-17. https://doi.org/https://doi.org/10.18860/jeasp. v2i1.7259

Nikolic, S., Stirling, D., \& Ros, M. (2018). Formative assessment to develop oral communication competency using YouTube: Self- and peer assessment in engineering. European Journal of Engineering Education, 43(4), 538-551. https://doi.org/10.1080/03043797.2017.1298569

Okoro, N. (2007). Strategiesfor Remedying poor communication skills of stupents. An Interdisciplinary Journal of Communication Studies, 6, 13-22.

Onoda S. (2014) An exploration of effective teaching approaches for enhancing the oral fluency of EFL students. In T. Muller, J. Adamson, P.S. Brown, \& S. Herder (Eds.), Exploring EFL fluency in Asia. Palgrave Macmillan London. https://doi.org/10.1057/9781137449405_8

Rahman, M. M. (2010). Teaching oral communication skills : A task-based approach. ESP World, 9(1), 1-11. https://doi.org/10.1080/10572259809364631

Saefurrohman, S. (2018). EFL Teachers Assessment Methods in Oral Communications. Advances in Social Science, Education and Humanities Research, 267, 268-272. https://doi.org/10.2991/aecon-18.2018.52

Şimon, S. (2014). Enhancing the English oral communication skills of the 1 st year students of the Bachelor's degree program "Communication and public relations." Procedia - Social and Behavioral Sciences, 116, 24812484. https://doi.org/10.1016/j.sbspro.2014.01.596

Soomro, M. A., Siming, I. A., Channa, M. A., Shah, S. H. R., Naeem, N., \& Abbasi, A. M. (2019). An analysis of English oral communication apprehension and anxiety of engineering undergraduates in Pakistan. International Journal of English Linguistics, 9(2), 162-173. https://doi.org/10.5539/ijel.v9n2p162

Subramaniam, Jeevi K., Gunadevi A., Pathma Fathima Harun, R. S. N. R. (2013). Polytechnic students ' perceptions of youtube usage in the english oral communication classroom. International Journal of Asian Social Science, 3(9), 1962-1966.

Subramaniam, G. K. J., \& Harun, R. N. S. R. (2012). Marketing Students' Perceptions and Their Experiences during Industrial Training on English Oral Communication Skills. Procedia - Social and Behavioral Sciences, 66, 283-289. https://doi.org/10.1016/j.sbspro.2012.11.270

Thu, N. T., Thi, N., \& Thu, K. (2016). Oral English communication strategies among Vietnamese non-majors of English at intermediate level. American Journal of Educational Research, 4(3), 283-287. https://doi. org/10.12691/education-4-3-9

Tipmontree, S., \& Tasanameelarp, A. (2018). The effects of role-playing simulation activities on the improvement of EFL students' business English oral communication. Journal of Asia TEFL, 15(3), 735-749. https://doi. org/10.18823/asiatefl.2018.15.3.11.735

Tsai, I. I. yin. (2019). The effect of peer collaboration-based learning on enhancing English oral communication proficiency in MICE. Journal of Hospitality, Leisure, Sport and Tourism Education, 24, 38-49. https://doi. org/10.1016/j.jhlste.2018.10.006

Tuomaitė, V., \& Zajankauskaitė, Z. (2017). Oral communication in a foreign language competence development in academic contexts. Studies About Languages, (31), 113-129. https://doi.org/10.5755/j01.sal.0.31.19049

Wang, B., Teo, T., \& Yu, S. (2017). Teacher feedback to student oral presentations in EFL classrooms: a case study. Journal of Education for Teaching, 43(2), 262-264. https://doi.org/10.1080/02607476.2016.1257507

Wang, B., Yu, S., \& Teo, T. (2018). Experienced EFL teachers' beliefs about feedback on student oral presentations. Asian-Pacific Journal of Second and Foreign Language Education, 3(1), Article 12. https://doi.org/10.1186/ s40862-018-0053-3

Zukurnain, N., \& Kaur, S. (2014). Oral English communication difficulties and coping strategies of diploma of hotel management students at UiTM. 3L: The Southeast Asian Journal of English Language Studies, 20(3), 93-112. http://ejournals.ukm.my/31/article/view/6078/2971 